Article

\title{
Empirical studies on the performance of banks: A systematic literature review for future research
}

\author{
S G Sisira Dharmasri Jayasekara ${ }^{1 *}$, K L Wasantha Perera ${ }^{2}$, and A Roshan Ajward ${ }^{3}$ \\ 1 Faculty of Management Studies and Commerce, University of Sri Jayewardenepura, Nugegoda, Sri Lanka ; \\ sisiradj@cbsl.lk \\ 2 Senior Lecturer, Department of Finance, Faculty of Management Studies and Commerce, University of Sri \\ Jayewardenepura, Nugegopda, Sri Lanka; wasantha.perera@sjp.ac.lk \\ 3 Senior Lecturer, Department of Accounting, Faculty of Management Studies and Commerce, University of \\ Sri Jayewardenepura, Nugegoda, Sri Lanka ; ajward@sjp.ac.lk \\ * Correspondence: sisiradj@cbsl.lk; Tel.:+94112866046
}

Received: 1 May 2020; Accepted: 30 June 2020; Published: 1 July 2020.

\begin{abstract}
This paper intends to review research on the performance of banks to identify gaps in the current body of knowledge to justify future research directions. We use a systematic literature review method and review 164 articles from refereed journals. Content analysis reveals that most of the studies are empirical focusing on two aspects i.e. financial performance and efficiency of banks. These studies consider the impact of particular events and contexts on performance and efficiency while testing research hypotheses. However, often there is a lack of a theoretical backing for these studies. We argue that the considered events and contexts affect the risk transformation process under the financial intermediation theory. The efficiency of banks reflects the risk transformation process and causes performance. On the other hand, traditional performance indicators were based on financial measures that do not reflect the components of the risk transformation process. A sound comprehensive risk-based composite measure is required to fill this gap.
\end{abstract}

Keywords: systematic literature review; financial intermediation; efficiency; performance; banks.

JEL codes: E32, G21, M41.

\section{Introduction}

A function of a bank differs from other business firms. The main economic functions of the banks are those of consolidating and transforming risks on the one hand by providing credits in the deficit sector and reducing the cost of transaction and information costs on the other hand. The theory of banking firm explains the risk transformation process. In this context, the performance of banks is a very popular research area over the years which focuses on the impact of a selected context or an event on the performance. These studies cover the banking process as well as the management issues of banks. The banking process has been discussed in different theoretical perspectives. However, most performance studies have been empirical studies that lack a sound theoretical foundation on the backing process. Three theories have emerged over time in the banking process i.e. credit creation theory, fractional reserve theory, and financial intermediation theory. Today, financial intermediation theory is dominant in the banking process. Some other theories are related to the management issues of banks i.e. agency theory, stakeholder theory, trade-off theory, resource-based theory, moral hazard theory, and capital buffer theory, among others. We will focus on the performance of banks under the banking process in terms of financial intermediation theory. 
Empirical studies show that performance measures depend on the objectives of the researcher. There is no unique measure of performance and therefore, the same study has used several measures to capture the performance. However, unique results among different measures have not been generated. Therefore, this study intends to review the empirical work to identify a suitable method of measuring the performance of banks in different research perspectives or context. Therefore, the purpose of this study is to provide an extensive literature review on the performance of banks. More specifically, the objectives of the study are to:

1. Synthesize the existing literature on the performance of banks.

2. Arrange the publications in an orderly manner to enable easy and quick search.

3. Classify performance research articles according to their approach and methodologies.

4. Explore the issues in performance research and suggest research areas for future work.

This study also focuses on the following research questions in addition to the above objectives. These questions will guide us to have a comprehensive understanding of the research context.

- How articles on bank performance are placed in time?

- What has been studied about performance?

- What research methods have been used?

- What are the most important articles about the topic?

The remainder of the paper is organized as follows. We first introduce the concept of performance of banks and research methodology. Second, we provide an article classification scheme. Thereafter, an overview of the selected publications is provided. Finally, we outline our main findings, discuss implications, and suggest avenues for future research.

\section{Concept of Performance of Banks}

Cambridge Dictionary defines performance as "how well a person, machine, etc. does a piece of work or activity". According to the Oxford dictionary, performance is the action or process of performing a task or function. We define the performance as how well a bank does the financial intermediation process in sustainably achieving the objectives of stakeholders. The performance of banks is assessed in different perspectives using financial as well as non-financial indicators of banks. Hughes \& Mester (2015) identify two broad approaches in measuring the performance of banks i.e. non-structural and structural approaches. Non-structural approaches use different performance measures (e.g. ROE, ROA, net interest margins, Tobin's q-ratio among others). In contrast, structural approaches are based on theoretical models of banking behavior such as efficient and profit frontiers. The efficiency measures how best a bank performs over the other banks in the industry in the process of converting inputs into outputs. Banks are different from the other business entities and they function as an intermediary between depositors and borrowers. Therefore, the performance of banks has to be measured considering the financial intermediation process. The overall long-term financial performance results in the financial stability of banks.

\section{The Methodology of the Literature Review}

A systematic approach was used to identify and select articles for the review. Fink (2005) suggests that a literature review must use a methodology that is systematic in approach, explicit in describing the procedures by which it was conducted and comprehensive in its scope of including all relevant material related to particular phenomena. Following Singh \& Kumar (2014), a four-category process was used as shown in Figure 1.

\subsection{Literature Collection and Boundary Identification}

We searched for articles in Elsevier and Emerald databases to capture a comprehensive and diverse range of articles published in Elsevier and Emerald databases for review. We started with a 
keyword search and then delimited the literature thereafter. Thus, it is a combination of deductive and inductive approaches (Singh \& Kumar, 2014; Shukla \& Jharkharia, 2013). The keyword search generated a sizable number of articles. We adopted the methodology used by Singh \& Kumar (2014) to filter the most relevant literature. The boundaries for selecting papers were given as follows:

- $\quad$ Papers published only in peer-reviewed indexed academic journals were considered.

- $\quad$ Papers were collected for 13 years (2008-2020).

- Papers with full-text available were considered.

This literature search was carried out considering the keywords within the boundaries to identify a sample for further screening. We used the performance of banks as the keyword and checked in titles, keywords, or abstracts for the identification. The first round search generated 795 articles within delimiting boundaries. Subsequently, we filtered the articles to identify the most relevant articles for our research context. This filtering process was carried out by reading the identified papers considering the relevance and appropriateness. The detailed comprehensive analysis produced 164 articles and was qualified for the final review. The protocol for the database search is illustrated in Table 1. The summary of the systematic process of article selection is presented in Figure 2. We searched Elsevier and Emerald databases from 2008 to 2020 on 19.11.2019.

Figure 1. Process of Systemic Literature Review

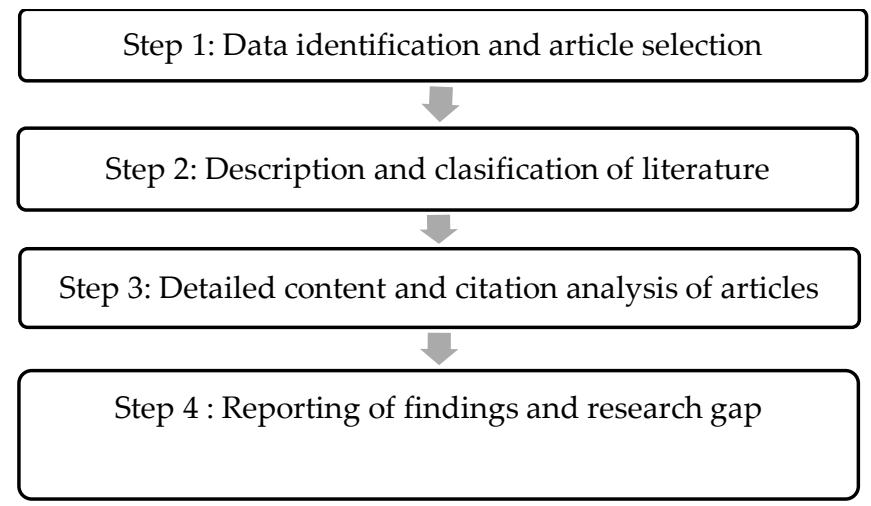

Source: Singh \& Kumar (2014),

Table 1. Database Search Protocol

\begin{tabular}{cccc}
\hline Database & Scope & $\begin{array}{c}\text { Number of } \\
\text { articles }\end{array}$ & Number of selected articles \\
\hline Elsevier & Title/abstract/keywords & 704 & 141 \\
Emerald & Title/abstract/keywords & 91 & 23 \\
Total & & 795 & 164 \\
\hline
\end{tabular}

Note: Search Date: 19.11.2019, period: 2008-2020

\section{Description and Classification of Literature}

The identified 164 were analyzed through the systemic literature review concerning the publication year, coverage of the study period, the methodology used, journal of publication, types of banking sector studied, country of studies, and source of data to understand the trends and issues in the literature.

\subsection{Analysis by Year of Publication}

This analysis intends to identify significant contexts and events through the dispersion of articles over the sample period. The analysis shows that the selected articles have been published quite 
regularly from 2008- 2020 as shown in figure 3. There is a scarce number of publications in the 20082010 period. The figure also confirms an upward trend in the number of publications, 2011 onward which could be attributed due to the empirical studies on the global financial crisis and performance. Most published articles are concentrated in 2016 and 2018. A maximum of 33 articles was published in the year 2018.

Figure 2. Summary of The Articles Selection Process of The Study

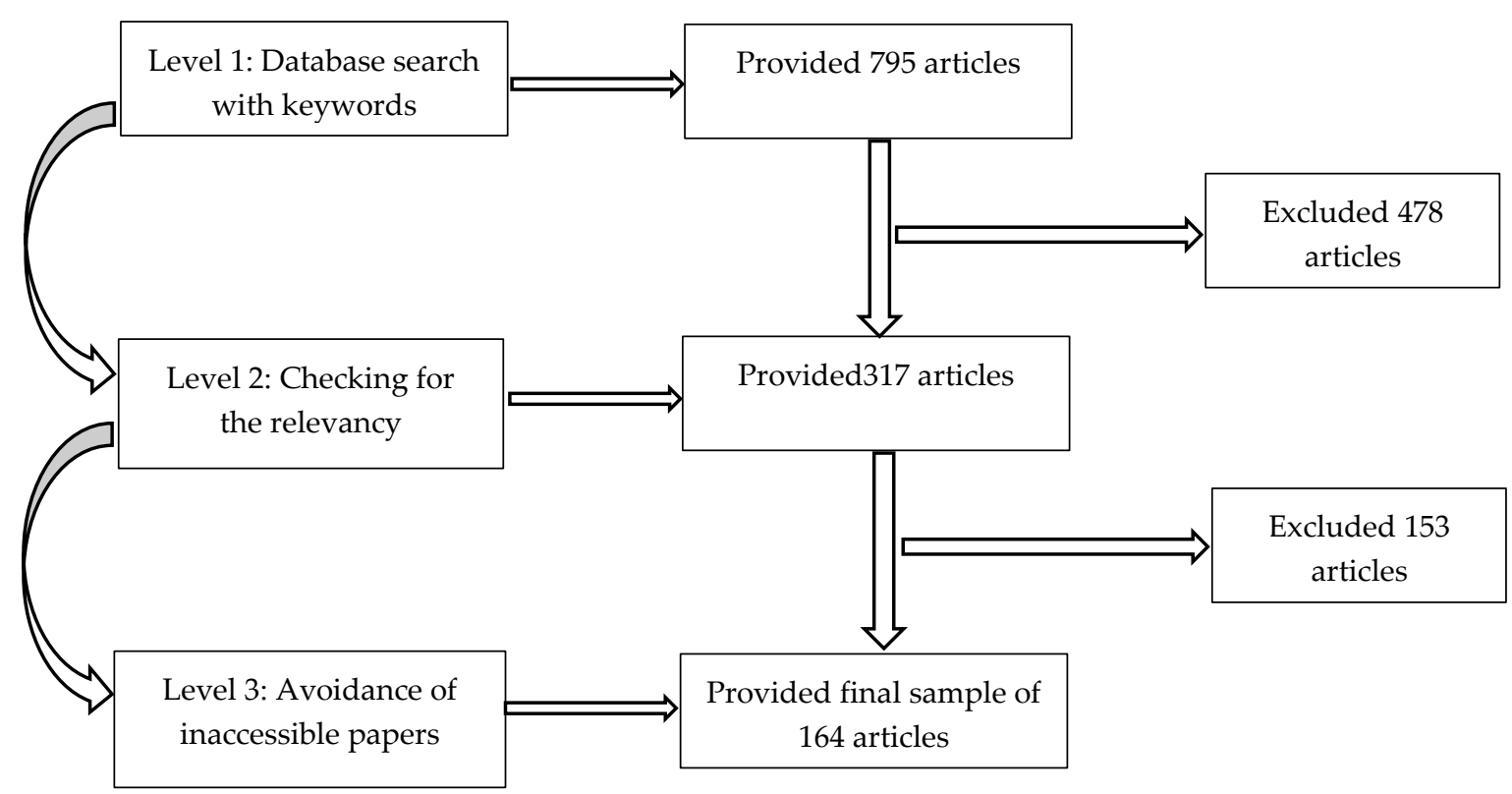

Source: Developed by the authors

Figure 3. Classification of Articles by Year of Publication

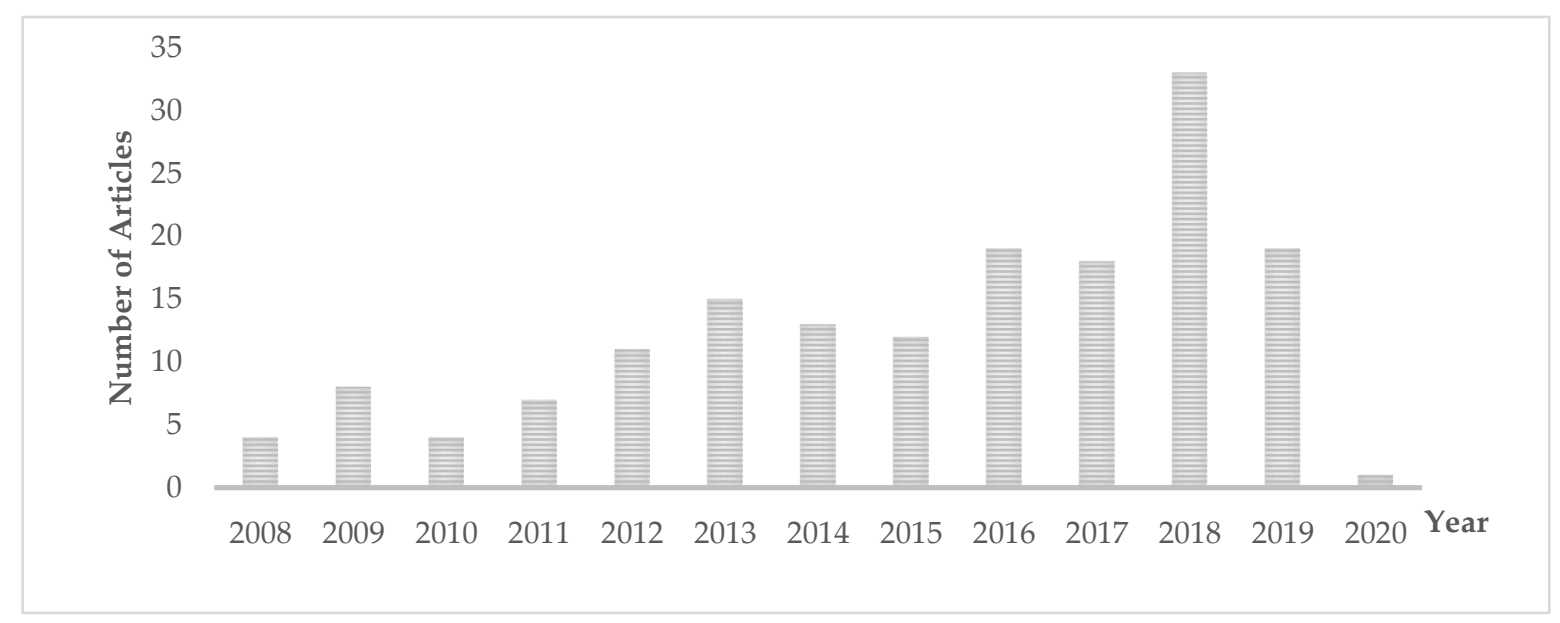

\subsection{Analysis by the coverage of the study periods}

Most of the reviewed articles had used panel data sets which creates an interest in analyzing the periods covered in the studies. Figure 4 shows the usage of data over the years by the selected papers. Most of the studies cover the period of the global financial crisis. The year 2007 has been included in most of the studies as a frequent data point. A sizable percentage of 65.24 of the selected papers have covered the year 2007 in respective studies. The period from 2005 to 2009 has been covered by more 
than 60 percent of studies. This shows the interest of researchers on studying the impact of events or context on the performance of banks.

Figure 4. Coverage of the study periods

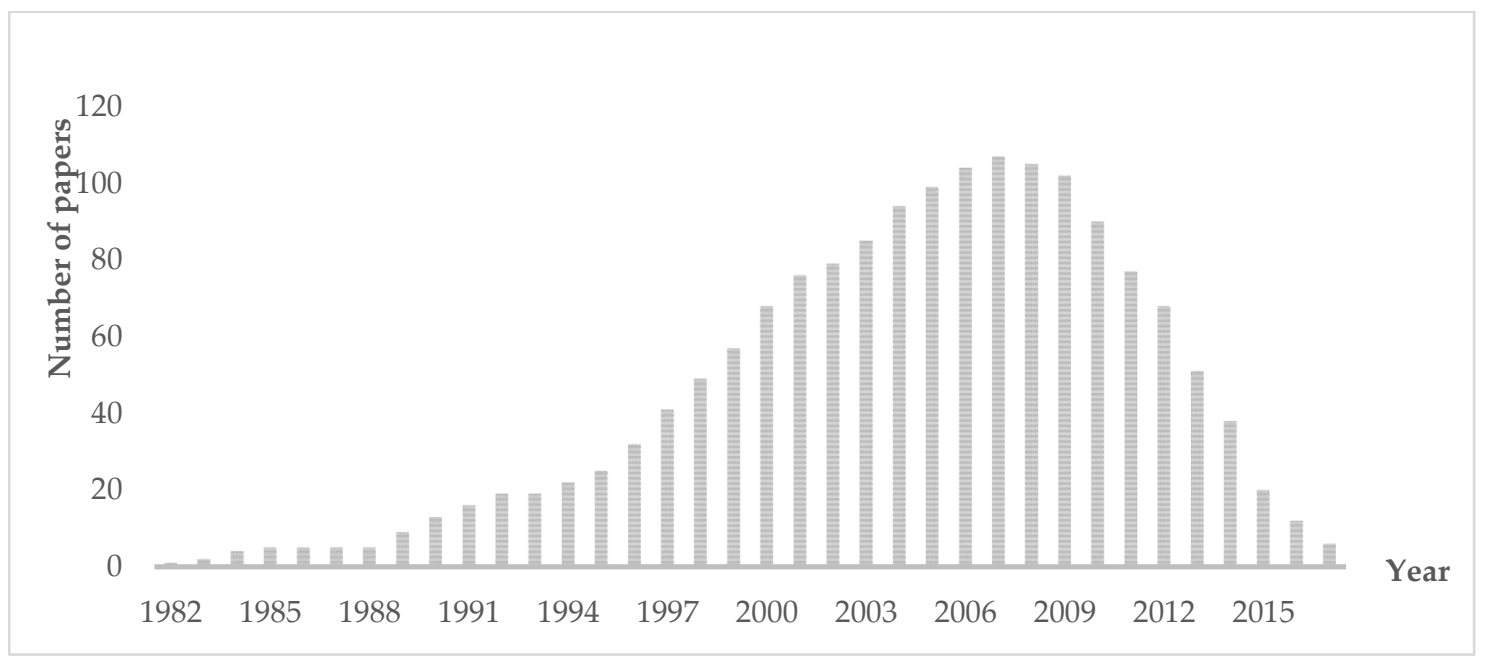

\subsection{Analysis by Research Methods}

The analysis reveals that all the papers were empirical studies. Table 2 shows the frequency of different empirical methodologies of our sample. We can identify three categories of empirical studies which include empirical panel data, OLS regression, and other measures of efficiency including Data Envelopment Analysis (DEA), Stochastic Frontier Approach (SFA), and cost efficiency measures among others. The panel data analysis has been the most popular methodology which represents 59.76 percent of total studies. Under the panel data, the majority has focused on the system generalized method of the moment. On the other hand, only forty-two studies are based on other efficiency-based performance measures.

Table 2. Articles by Research Methods

\begin{tabular}{ccc}
\hline Research method & Number & Percentage (\%) \\
\hline Panel Data & 98 & 59.76 \\
OLS Regression & 24 & 14.63 \\
Efficiency based methods & 42 & 25.61 \\
Total & 164 & 100.00 \\
\hline
\end{tabular}

\subsection{Analysis by the journal of publication}

This analysis is used to identify the most influential and involved journals which may be useful for future researchers and also will be useful to continue the conversation on the performance of banks. Our sample was contained in 59 journals as shown in Figure 5. Journal of Banking and Finance provides a maximum of twenty articles, followed by the Journal of Financial Stability with thirteen articles.

\subsection{Analysis by Type of Banks}

The performance studies cover all the subgroups in the banking industry. However, there are some specific studies on commercial banks, investment banks, savings banks. And also, the different types of characteristics such as government, private, and foreign ownership, or listed in stock exchange are considered. Our review suggests that commercial banks are dominant in performance studies. However, recent articles show a trend of studying the performance of Islamic banks concerning the 
performance of conventional banks (Majid, Falahaty, \& Jusoh, 2017; Alam, Zainuddin, \& Rizvi, 2019; Azad, Azmat, \& Hayat, 2019; Berger, Boubakri, Guedhami, \& Li, 2019). The majority of articles are cross-country studies which indicates an attempt to compare outcomes and findings across countries. Our analysis reveals that there are differences in performance among different categories of banks. For example, Köhler(2015) shows that listed banks have a significantly higher share of non-interest income and they are also more dependent on non-deposit funding than banks that are not listed. This might reduce the benefit of diversifying into non-interest income and non-deposit funding. Beck, Demirgüç-Kunt, \& Merrouche (2013) show the better stock performance of listed Islamic banks due to their higher capitalization and better asset quality over the conventional banks. Zuhroh, Ismail, \& Maskie (2015) show that Islamic banks are efficient over the conventional banks. Table 3 shows the frequency of articles for each subgroup of banks.

Figure 5. Articles by the Journal of Publications

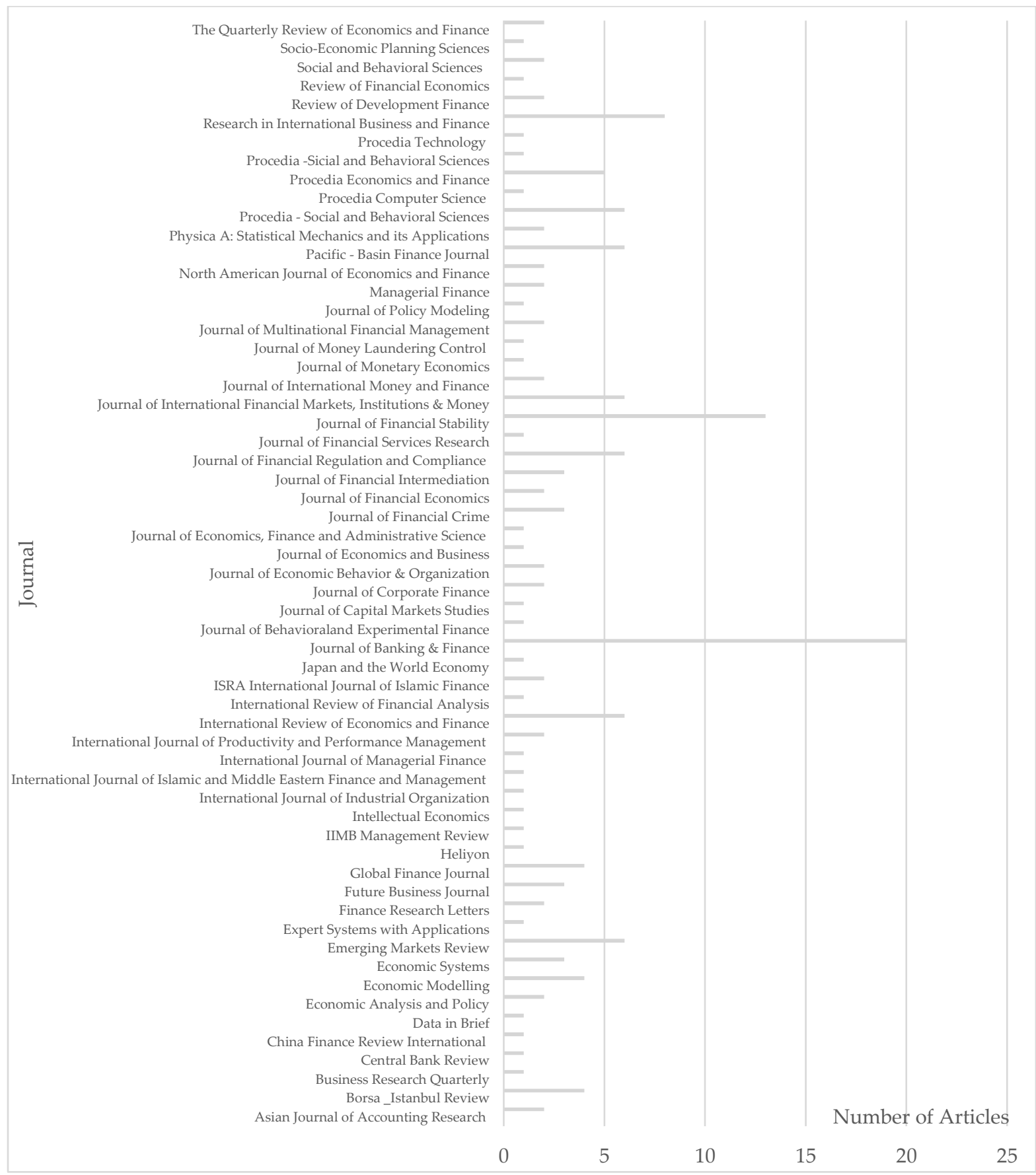


Table 3. Articles by Types of Banks

\begin{tabular}{ccc}
\hline Type of banks & $\begin{array}{c}\text { Number of } \\
\text { Articles }\end{array}$ & $\begin{array}{c}\text { Percentage } \\
\text { (\%) }\end{array}$ \\
\hline Banks (Including Commercial, Investments, and Savings banks) & 89 & 54.27 \\
Commercial Banks & 31 & 18.90 \\
Corporative Banks & 4 & 2.44 \\
Islamic Banks & 14 & 8.54 \\
Listed Banks & 12 & 7.32 \\
Others (Government, Private, Deposit Money banks) & 14 & 8.54 \\
\hline Total & 164 & 100.00 \\
\hline
\end{tabular}

\subsection{Analysis by Country of Studies}

The analysis by country of studies provides some peculiar insights from the literature. Figure 6 provides the mapping of countries based on the coverage of the number of studies. This shows that performance studies are concentrated in East Asian count and Eastern European countries over the other regions. We assume that the East Asian financial crises and the membership of the European Union by Eastern European countries have fueled the interest. Apart from these two regions, China, India, and the USA have been dominant in performance studies which may be due to the size and growth of economies where banks play a major role. It is a common observation that there is a trend of focusing on a group of countries or regions for the studies rather than concentrating on a single country. There is more concentration on Asia over other regions. Malaysia, Turkey, Indonesia, China, and India are the frequently studied countries during the period of the survey. A list of countries with ten or more research articles is presented in Figure 7.

Figure 6: Analysis by country of studies

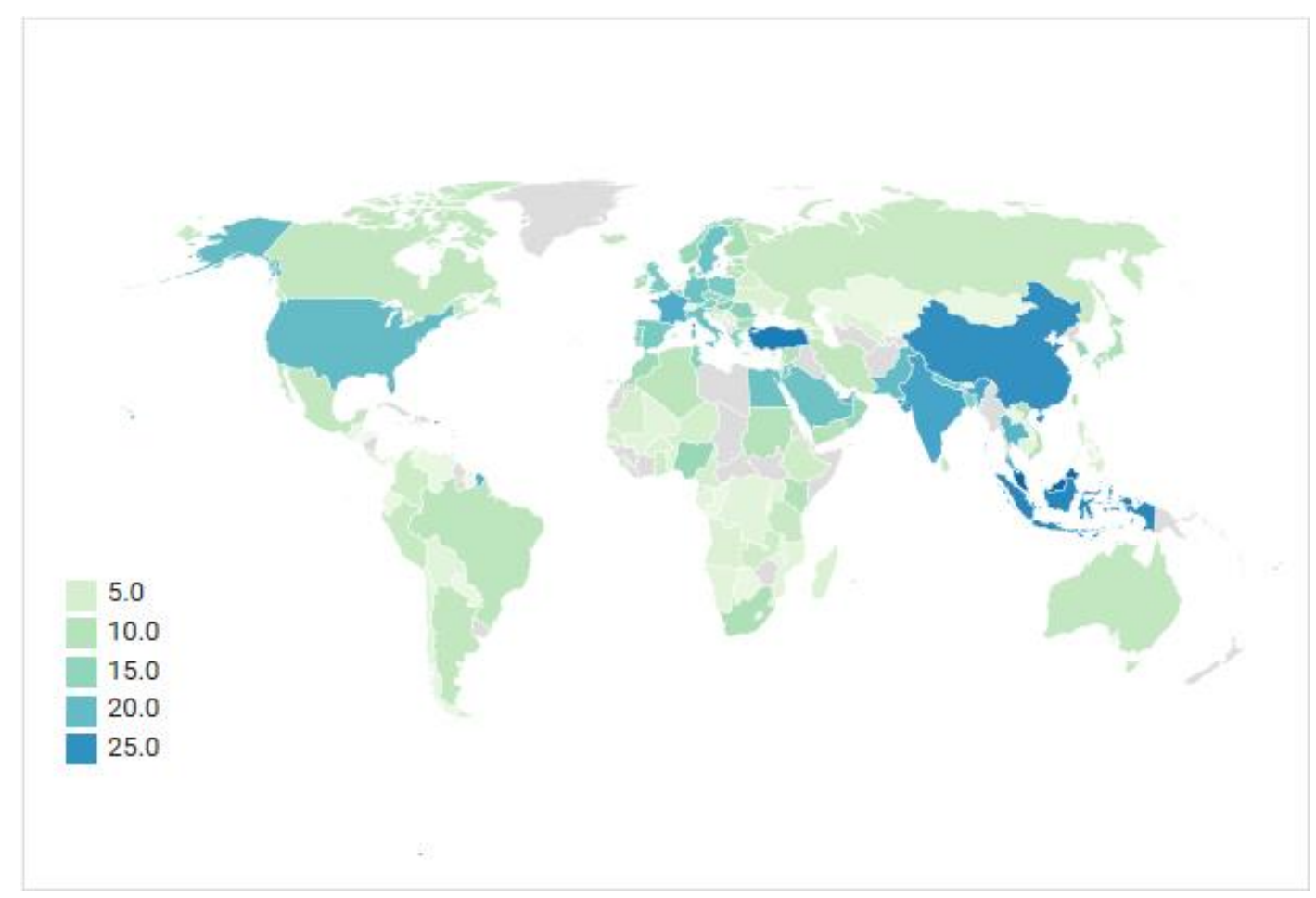

\subsection{Analysis by Source of Data}

The performance studies considered in this review had used secondary data to gather bank-level as well as country-level data. The bank Scope database was popular in obtaining bank-level data while 
the world development indicators compiled by the World Bank and International Financial Statistics database compiled by the International Monetary Fund were popular for the macroeconomic data. The frequently used sources for bank-level data are shown in Table 4.

Figure 7. Frequently Researched Countries

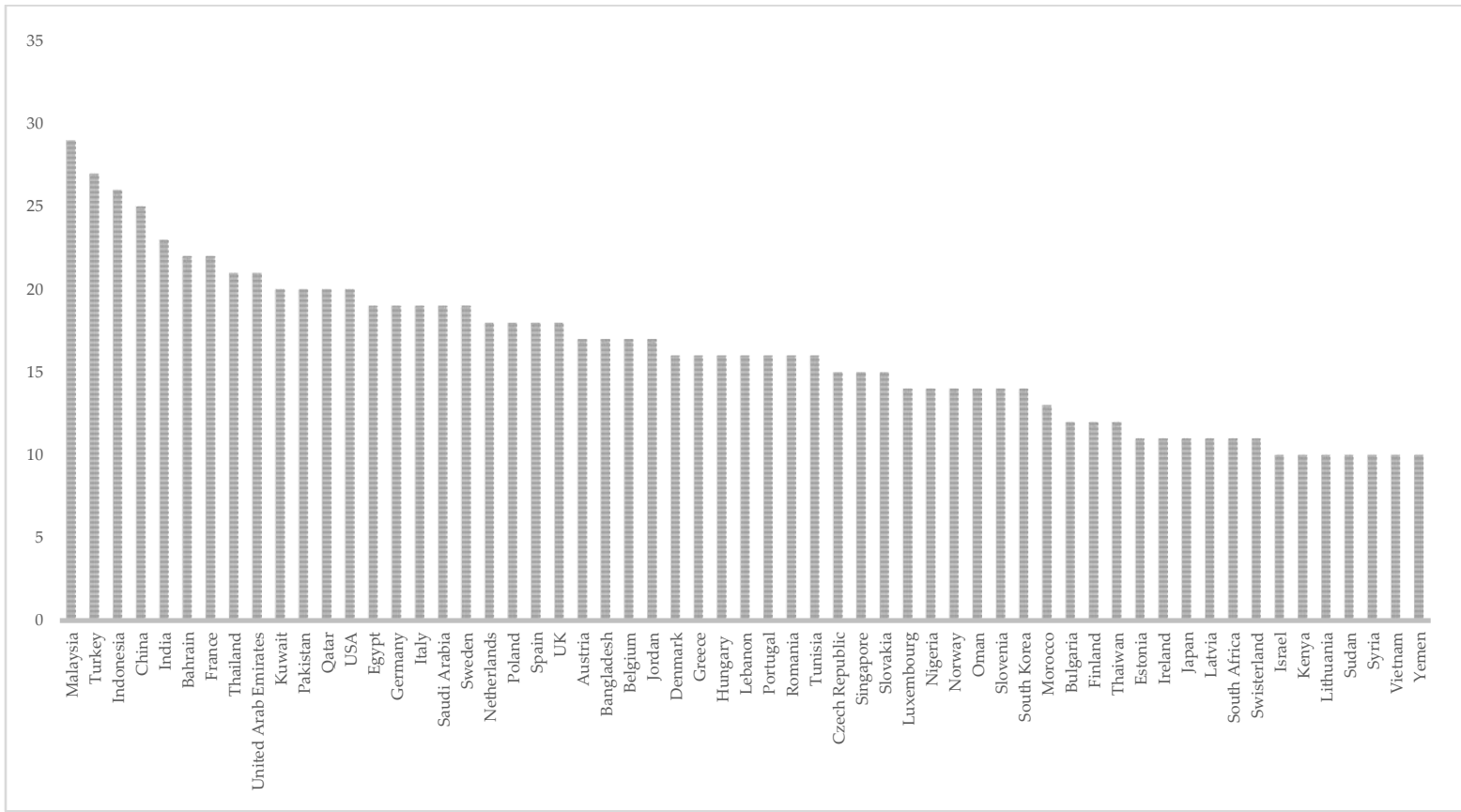

Table 4. Popular Databases for Bank-Level Data

\begin{tabular}{ccc}
\hline Database & Number of articles & Percentage (\%) \\
\hline Annual reports from bank websites & 19 & 11.59 \\
Bank Scope database & 104 & 63.41 \\
Central banks & 24 & 14.63 \\
Other sources & 17 & 10.37 \\
\hline Total & $\mathbf{1 6 4}$ & $\mathbf{1 0 0 . 0 0}$ \\
\hline
\end{tabular}

\section{Citation Analysis}

A citation is a reference to the work of another author/s in someone's academic work. Citation analysis is the study of cited references for a population of articles to find the most influential works in the field (Singh \& Kumar, 2014). Google Scholar is used to capturing citation information of the sample. Our analysis found that only 141 of the 164 articles had been cited. Most of the uncited articles have been published recently during 2018-2020. The cited 141 articles count 12,758 cited references at an average of 80 per article. The most-cited articles with at least 100 citations are shown in Table 5 . (Athanasoglou, Brissimis, \& Delis (2008) is the most-cited article with 1474 citations. Andres \& Vallelado (2008), Beck, Demirgüç-Kunt, \& Merrouche (2013), Berger \& Bouwman (2013), and Demirguc-Kunt \& Huizinga (2010) were also among the top five most-cited publications.

Table 6 presents the most referenced journals that published work on the performance of banks. In social sciences, academic accreditation is recognized as the publications in ranked journal databases i.e. ABDC, ABS, Scopus, and ISI. The social science academic community requires the ranked journal in ABDC \& ABS to be included in the Scopus index 


\section{Content Analysis}

Content analysis is a class of methods within social science that can be applied both in quantitative and qualitative ways (Singh \& Kumar, 2014). The content analysis is used to see what the other authors have done in their studies. Detailed content analysis of our sample reveals that most of the studies on the performance of banks have been focused on the financial performance and efficiency of banks considering determinant factors. These studies have not considered the financial intermediation process in performance measurements. Most of the studies focus on the impact of a given event, scenario, or context on the performance and efficiency of banks. For example, the impact of capital on bank performance during financial crises; bank bailouts and bank performance; non-performing loans and bank efficiency; bank political connections and performance; bank reforms, foreign ownership, and financial stability; bank regulation and efficiency; bank regulations, competition, and financial reforms on banks' performance; bank supervision, regulation, and efficiency; banking sector reform and performance; board diversity and its effects on bank performance; board structure and performance; CEO education and bank performance; corporate governance and bank performance; corporate social responsibility and financial performance; determinants of bank performance and bank efficiency; were popular among other areas. We propose that the above events and contexts affect the intermediation process that can be measured in terms of efficiency. This efficiency causes the shortterm performance of banks which is measured by using accounting ratios and long- term performance in terms of stability.

Table 5. List of Articles with More Than 100 Citations

\begin{tabular}{|c|c|c|c|}
\hline Number & Author/s & Year & $\begin{array}{c}\text { Number of } \\
\text { citations }\end{array}$ \\
\hline 1 & Athanasoglou, P. P., Brissimis, S. N., \& Delis, M. D. & 2008 & 1474 \\
\hline 2 & Andres, P. d., \& Vallelado, E. & 2008 & 769 \\
\hline 3 & Beck, T., Demirgüç-Kunt, A., \& Merrouche, O. & 2013 & 756 \\
\hline 4 & Berger, A. N., \& Bouwman, C. H. & 2013 & 753 \\
\hline 5 & Demirguc--Kunt, A., \& Huizinga, H. & 2010 & 727 \\
\hline 6 & Kosmidou, $\mathrm{K}$ & 2008 & 593 \\
\hline 7 & Berger, A. N., Hasan, I., \& Zhou, M. & 2010 & 379 \\
\hline 8 & Berger, A. N., Klapper , L. F., \& Turk-Ariss , R. & 2009 & 374 \\
\hline 9 & García-Herrero, A., Gavilá, S., \& Santabárbara, D. & 2009 & 372 \\
\hline 10 & Uhde, A., \& Heimeshoff, U. & 2009 & 353 \\
\hline 11 & Naceur, S. B., \& Omran, M. & 2010 & 347 \\
\hline 12 & Seçme , N. Y., Bayrakdaroğlu, A., \& Kahraman , C. & 2009 & 342 \\
\hline 13 & Brissimis, S. N., Delis, M. D., \& Papanikolaou, N. I. & 2008 & 329 \\
\hline 14 & Bertay, A. C., Demirgüç-Kunt, A., Huizinga, H. & 2013 & 315 \\
\hline 15 & Chortareas, G. E., Girardone, C., \& Ventouri, A. & 2012 & 290 \\
\hline 16 & Cornett, M. M., Guo, L., Khaksari, S., Tehranian, H. & 2010 & 285 \\
\hline 17 & Berger, A. N., Kick, T., \& Schaeck, K. & 2014 & 254 \\
\hline 18 & Pathan, S., \& Faff, R. & 2013 & 225 \\
\hline 19 & Fu, X., Lin, Y., \& Molyneux, P. & 2014 & 218 \\
\hline 20 & Naceur, S. B., \& Kandil, M. & 2009 & 215 \\
\hline 21 & Distinguin, I., Roulet, C., \& Tarazi, A. & 2013 & 213 \\
\hline 22 & Shim, J. & 2013 & 176 \\
\hline 23 & Rossi, S. P., Schwaiger, M. S., \& Winkler, G. & 2009 & 156 \\
\hline 24 & Meca, E. G., Sánchez, I.-M. G., \& Ferrero, J. M. & 2015 & 156 \\
\hline 25 & Mirzaei, A., Moore, T., \& Liu, G. & 2013 & 140 \\
\hline 26 & Manthos , D., \& Nikolaos , I. I. & 2009 & 132 \\
\hline 27 & Ashraf, Q., Gershman, B., Howitt, P. & 2017 & 128 \\
\hline 28 & Köhler, M. & 2015 & 122 \\
\hline 29 & Hong, H., Huangb, J.-Z., \& Wu, D. & 2014 & 107 \\
\hline 30 & Cubillas, E., Fonseca, A. R., \& González, F. & 2012 & 103 \\
\hline 31 & Fukuyama, H., \& Matousek, R. & 2011 & 100 \\
\hline
\end{tabular}


Table 6. List of Most-cited Journals and the Ranking

\begin{tabular}{|c|c|c|c|c|c|}
\hline Number & Journal & 胥 & $\underset{\sim}{\mathbb{W}}$ & $\begin{array}{c}\text { Number of } \\
\text { Papers }\end{array}$ & $\begin{array}{c}\text { Number of } \\
\text { Citations }\end{array}$ \\
\hline 1 & Journal of Banking \& Finance & $A^{*}$ & 3 & 20 & 4508 \\
\hline 2 & Journal of Int. Financial Markets, Institutions \& Money & A & 3 & 7 & 1675 \\
\hline 3 & Journal of Financial Economics & $A^{*}$ & $4^{*}$ & 2 & 1485 \\
\hline 4 & Journal of Financial Stability & A & 3 & 13 & 725 \\
\hline 5 & Managerial Finance & $\mathrm{B}$ & 1 & 2 & 725 \\
\hline 6 & Journal of Financial Intermediation & $A^{*}$ & 4 & 3 & 683 \\
\hline 7 & Emerging Markets Review & A & 2 & 6 & 404 \\
\hline 8 & Journal of Financial Services Research & A & 3 & 1 & 374 \\
\hline 9 & Expert Systems with Applications & $\mathrm{C}$ & 2 & 1 & 342 \\
\hline 10 & Journal of Corporate Finance & $A^{*}$ & 4 & 2 & 285 \\
\hline 11 & Journal of Economics and Business & B & 1 & 1 & 215 \\
\hline 12 & Procedia - Social and Behavioral Sciences & - & - & 6 & 136 \\
\hline 13 & Journal of Economic Behavior \& Organization & $A^{*}$ & 3 & 2 & 128 \\
\hline 14 & Procedia Economics and Finance & - & - & 5 & 107 \\
\hline 15 & International Review of Economics and Finance & A & 2 & 6 & 91 \\
\hline 16 & Journal of Monetary Economics & $A^{*}$ & 4 & 1 & 91 \\
\hline 17 & Journal of International Money and Finance & $\mathrm{A}$ & 3 & 2 & 85 \\
\hline 18 & Socio-Economic Planning Sciences & $\mathrm{C}$ & 2 & 1 & 84 \\
\hline 19 & Journal of Financial Regulation and Compliance & $\mathrm{C}$ & - & 6 & 81 \\
\hline 20 & Research in International Business and Finance & $\mathrm{B}$ & - & 8 & 60 \\
\hline 21 & Economic Modelling & A & 2 & 4 & 48 \\
\hline 22 & Borsa_Istanbul Review & - & - & 4 & 47 \\
\hline 23 & Economic Systems & $\mathrm{B}$ & 2 & 3 & 42 \\
\hline 24 & Pacific-Basin Finance Journal & A & - & 6 & 41 \\
\hline 25 & Review of Development Finance & - & 2 & 2 & 39 \\
\hline 26 & Journal of Multinational Financial Management & $\mathrm{B}$ & 2 & 2 & 36 \\
\hline 27 & International Journal of Industrial Organization & A & 3 & 1 & 33 \\
\hline 28 & Physica A: Statistical Mechanics and its Applications & - & & 2 & 23 \\
\hline 29 & Future Business Journal & - & - & 3 & 21 \\
\hline 30 & Journal of Money Laundering Control & $\mathrm{C}$ & - & 1 & 17 \\
\hline 31 & Social and Behavioral Sciences & - & - & 2 & 17 \\
\hline 32 & International Review of Financial Analysis & A & 3 & 1 & 15 \\
\hline 33 & Japan and the World Economy & $\mathrm{B}$ & 1 & 1 & 15 \\
\hline 34 & The Quarterly Review of Economics and Finance & - & - & 2 & 12 \\
\hline 35 & Global Finance Journal & A & 2 & 4 & 8 \\
\hline 36 & Economic Analysis and Policy & B & 2 & 2 & 7 \\
\hline 37 & Intellectual Economics & $A^{*}$ & - & 1 & 7 \\
\hline 38 & Finance Research Letters & $\mathrm{A}$ & 2 & 2 & 6 \\
\hline 39 & Heliyon & - & - & 1 & 6 \\
\hline 40 & International Journal of Managerial Finance & A & - & 1 & 6 \\
\hline 41 & China Finance Review International & $\mathrm{C}$ & - & 1 & 5 \\
\hline 42 & Journal of Financial Crime & B & - & 3 & 5 \\
\hline 43 & Journal of Policy Modeling & A & - & 1 & 4 \\
\hline 44 & Review of Financial Economics & B & 1 & 1 & 3 \\
\hline 45 & Benchmarking: An International Journal & $\mathrm{B}$ & - & 1 & 2 \\
\hline 46 & Central Bank Review & $\mathrm{C}$ & - & 1 & 2 \\
\hline 47 & Int. Journal of Productivity and Performance Management & $\mathrm{B}$ & - & 2 & 2 \\
\hline 48 & North American Journal of Economics and Finance & - & 2 & 2 & 2 \\
\hline 49 & Procedia Technology & - & - & 1 & 2 \\
\hline 50 & Journal of Capital Markets Studies & - & - & 1 & 1 \\
\hline \multicolumn{4}{|c|}{ Total } & 154 & 12,758 \\
\hline
\end{tabular}

${ }^{*}$ ABDC, Ranking as per the 2019 Australian Business Deans Council (ABDC) Journal Quality List. CABS (AJG), Ranking of Chartered Association of Business Schools. Scopus index list. ISI, International Scientific Indexing 


\subsection{Financial Performance of Banks}

Various financial ratios or indicators, dependent variables, have been used to measure the performance of banks in respect of identified issues. Frequently, some studies have used several financial indicators as dependent variables to maintain the robustness of the studies. Commonly used performance indicators are shown in table 7.

Table 7. Frequently Used Performance Measures of Banks

\begin{tabular}{|c|c|}
\hline Author/s & Performance Indicator/ Dependent variable/s \\
\hline Hughes, Jagtiani, Mester, \& Moon (2019) & ROA, Tobin's Q \\
\hline Robin, Salim, \& Bloch (2018) & ROA, ROE, NIM \\
\hline Dedu \& Chitan ( 2013) & ROA, ROE, Z-score \\
\hline Fang, Lau, Lu, Tan, \& Zhang (2019) & ROA, NIM \\
\hline James \& Joseph (2015) & $\mathrm{ROA}$ \\
\hline Meca, Sánchez, \& Ferrero (2015) & ROA, Tobin's Q \\
\hline Pathan \& Faff (2013) & ROAA, ROAE. Tobin's Q, NIM, Stock returns \\
\hline Mahbub, Matthew, \& Barker (2019) & ROA \\
\hline Alam, Zainuddin, \& Rizvi (2019) & ROA, non-interest net revenue \\
\hline Kutubi, Ahmed, \& Khan (2018) & ROA, Tobin's Q \\
\hline Oyewumi, Ogunmeru, \& Oboh (2018) & $\mathrm{ROA}$ \\
\hline Khan, Ahmad, \& Chan (2018) & ROAA, ROAE \\
\hline Köster \& Pelster (2017) & Profit before tax, profit after tax \\
\hline $\begin{array}{l}\text { Onakoya, Moses, Olokundun, Okorie, \& Lawal } \\
\text { (2018) }\end{array}$ & ROA, ROE, NIM, and Tobin's Q \\
\hline Chen, Liang, \& Yu (2018) & NPL, ROA, ROE, NIM, and Cost to income ratio \\
\hline Huang, Chiang, \& Lin ( 2017) & ROA, Z-score, Loan loss provision ratio \\
\hline Azad, Azmat, \& Hayat(2019) & NIM \\
\hline Bandt, Camara, Maitre, \& Pessarossi (2018) & ROA, Capital ratio \\
\hline Bian \& Dend (2017) & ROA, ROE, NPL \\
\hline King, Srivastav, \& Williams (2016) & Industry adjusted ROA \\
\hline Musali \& Ismail (2014) & ROA, ROE \\
\hline Maqbool \& Zameer (2018) & $\begin{array}{c}\text { A composite index of performance (ROE, ROA, NP, SR, } \\
\text { and PE) }\end{array}$ \\
\hline Rashid \& Jabeen (2016) & $\begin{array}{l}\text { A financial performance index using CAMELS } \\
\text { variables. }\end{array}$ \\
\hline
\end{tabular}

The studies have considered two determinant factors on the performance of banks .i.e. internal and external factors. According to Robin, Salim, \& Bloch (2018), the internal determinants are related to bank-specific variables. Commonly used internal factors in determining the financial performance of banks are shown in the following table.

The external determinants are industry-specific and macro-economic variables. Therefore, they are recognized to be external or market variables in determining performance. Commonly used external factors in determining financial performance are; GDP growth rate(Robin, Salim, \& Bloch, 2018; Fang, Lau, Lu, Tan, \& Zhang, 2019; Alam, Zainuddin, \& Rizvi,2019; Kutubi, Ahmed, \& Khan, 2018 ;Köster \& Pelster,2017; Chen, Liang, \& Yu, 2018), inflation(Robin, Salim, \& Bloch, 2018; Fang, Lau, Lu, Tan, \& Zhang, 2019; Alam, Zainuddin, \& Rizvi, 2019; Kutubi, Ahmed, \& Khan, 2018; Chen, Liang, \& Yu, 2018), interest rate (Köster \& Pelster,2017), budget surplus(Chen, Liang, \& Yu, 2018), exchange rate (Chen, Liang, \& Yu, 2018), government debt (Gerhardt \& Vennet,2017) , housing prices (Gerhardt \& Vennet,2017), among other variables. 
Table 8. Commonly Used Internal Determinants of Financial Performance Of Banks

\begin{tabular}{|c|c|}
\hline Variable & Author/s \\
\hline Capital & $\begin{array}{l}\text { Robin, Salim, \& Bloch, 2018; Fang, Lau, Lu, Tan, \& Zhang, 2019; Pathan \& Faff, } \\
\text { 2013; Mahbub, Matthew, \& Barker, 2019; Alam, Zainuddin, \& Rizvi, 2019; } \\
\text { Kutubi, Ahmed, \& Khan, 2018;Köster \& Pelster,2017; Bandt, Camara, Maitre, \& } \\
\text { Pessarossi, 2018. }\end{array}$ \\
\hline Credit risk & $\begin{array}{l}\text { Robin, Salim, \& Bloch, 2018; Fang, Lau, Lu, Tan, \& Zhang, 2019; Mahbub, } \\
\text { Matthew, \& Barker, 2019; Chen, Liang, \& Yu, 2018; Gerhardt \& } \\
\text { Vennet,2017;Ghosh, 2018; Bandt, Camara, Maitre, \& Pessarossi, 2018; Boubakri, } \\
\text { Mirzaei, \& Samet, 2017. }\end{array}$ \\
\hline Loans to total assets & $\begin{array}{c}\text { Ghosh, 2018; Hung, Jiang, Liu, Tu, \& Wang, 2017; Bandt, Camara, Maitre, \& } \\
\text { Pessarossi, 2018. }\end{array}$ \\
\hline Bank size & $\begin{array}{l}\text { Fang, Lau, Lu, Tan, \& Zhang, 2019; Pathan \& Faff, 2013; Alam, Zainuddin, \& } \\
\text { Rizvi, 2019; Kutubi, Ahmed, \& Khan, 2018, 2018; Oyewumi, Ogunmeru, \& Oboh, } \\
\text { 2018; Khan, Ahmad, \& Chan, 2018; Köster \& Pelster,2017; Gerhardt \& } \\
\text { Vennet,2017; Chen, Liang, \& Yu ,2018; Bandt, Camara, Maitre, \& Pessarossi, 2018; } \\
\text { Boubakri, Mirzaei, \& Samet, 2017. }\end{array}$ \\
\hline Deposits to liabilities & Chen, Liang, \& Yu,2018 \\
\hline Liquidity & $\begin{array}{l}\text { Fang, Lau, Lu, Tan, \& Zhang, 2019; Köster \& Pelster,2017; Chen, Liang, \& Yu, } \\
\text { 2018; Boubakri, Mirzaei, \& Samet, 2017. }\end{array}$ \\
\hline Capital & $\begin{array}{l}\text { Gerhardt \& Vennet,2017; Ghosh, 2018; Hung, Jiang, Liu, Tu, \& Wang, 2017; Chen, } \\
\text { Liang, \& Yu ,2018; King, Srivastav, \& Williams, } 2016 .\end{array}$ \\
\hline Debts to equity & Chen, Liang, \& Yu, 2018; Bian \& Deng, 2017 \\
\hline Ownership & $\begin{array}{l}\text { Robin, Salim, \& Bloch 2018; Mahbub, Matthew, \& Barker, 2019; Kutubi, Ahmed, } \\
\text { \& Khan, } 2018\end{array}$ \\
\hline Market share & Mahbub, Matthew, \& Barker,2019; Khan, Ahmad, \& Chan, 2018. \\
\hline Diversification & $\begin{array}{l}\text { Fang, Lau, Lu, Tan, \& Zhang, 2019; Mahbub, Matthew, \& Barker, 2019; Bandt, } \\
\text { Camara, Maitre, \& Pessarossi, } 2018 .\end{array}$ \\
\hline
\end{tabular}

Source: Compiled by the author

\subsection{Efficiency of Banks}

The efficiency is another approach that is used to measure the performance. The efficiency measures how best a bank performs over the other banks in the industry in the process of converting inputs into outputs. There are various approaches to measure the efficiency of banks (see Table 9).

Studies on the efficiency of banks also have considered two types of determinants i.e.: internal and external (Manthos \& Nikolaos,2009; Mansour \& Moussawi, 2019). The internal factors are bankspecific and external factors are related to the external environment or the macroeconomy.

Most commonly identified internal factors in the literature were bank size (Mansour \& Moussawi, 2019; Partovi \& Matousek, 2019;Manthos \& Nikolaos, 2009; Miller \& Noulas, 1996; Sufian, Kamarudin, \& Nassir, 2016), ownership type ( Tecles \& Tabak, 2010), regulatory variables (Sufian et at, 2016; Das \& Ghosh, 2006) and level of problem loans, non-performing assets, ( Partovi \& Matousek, 2019 ; Berger \& Young, 1997), profitability(Mansour \& Moussawi, 2019), equity ratio(Mansour \& Moussawi, 2019). The most commonly identified macroeconomic variables are economic growth (Mansour \& Moussawi, 2019; Bencivenga \& Smith, 1991) and inflation factors (Mansour \& Moussawi, 2019). Some studies have considered the structure of the industry as a determinant of bank efficiency (Manthos and Nikolaos, 2009).

\section{Findings from Literature Review}

Our review of retrieved articles identifies some research gaps and limitations in research methods, study settings, and theoretical frameworks. We believe that the following issues are most relevant to the literature on the performance of banks. 
Table 9. Shows Various Approaches Of Measuring Efficiency Of Banks

\begin{tabular}{cc}
\hline Efficiency measure & Author/s \\
\hline $\begin{array}{c}\text { Censored stochastic } \\
\text { frontier model }\end{array}$ & Huang, Chiang, \& Lin, 2017; Tsai, Lin, \& Chen, 2015. \\
\hline $\begin{array}{c}\text { Stochastic frontier } \\
\text { analysis }\end{array}$ & $\begin{array}{c}\text { Ding \& Sickles, 2018; Shamshur \& Weill ,2019; Majid, Falahaty, \& Jusoh, 2017; } \\
\text { Psillaki \& Mamatzakis, 2017; Gunes \& Yildirim, 2016; Barros \& Williams, 2013; } \\
\text { Silva T. C., Tabak, Cajueiro, \& Dias, 2018. }\end{array}$ \\
\hline Profit frontier approach & Alcober, Prior, Ausina, \& Illueca, 2019. \\
\hline $\begin{array}{c}\text { Data Envelopment } \\
\text { Analysis }\end{array}$ & $\begin{array}{c}\text { Berger \& Mester,1997; Sathye ,2001;Barros, Chen, Liang, \& Peypoch, 2011; Batir, } \\
\text { Volkman, \& Gungor, 2017;Henriques, Sobreiro, \& Kimura, 2018;Colesnic, } \\
\text { Kounetas, \& Michael, 2019; Adesina ,2019; Mansour \& Moussawi,2019; Djalilov } \\
\text { \& Piesse,2019;Toloo \& Mensah,2019; Silva T. C., Tabak, Cajueiro, \& Dias, 2018. }\end{array}$ \\
\hline
\end{tabular}

Source: Compiled by the author

\subsection{Lack of Theoretical Backing For The Studies}

Most empirical studies are not backed by theories. Some papers link the results with resourcebased theories considering capital and other resources. Banks functions as intermediaries between depositors and borrowers which involve a risk transformation under the financial intermediation theory. Therefore, the performance of banks has to be studied in terms of the financial intermediation process. The previous studies lack a systematic combination of the empirical results of the performance of banks with the financial intermediation theory. We can identify two reasons for this limitation. First, the researchers have tried to link the impact of events or context with the performance. Secondly, researchers have focused on testing the hypotheses related to the performance and profitability of banks. This background provides an opportunity for extending the financial intermediation theory. We argue that the events and contexts affect the risk transformation process which can be measured in terms of efficiency under the financial intermediation theory. This improvement or efficiency of the process affects the short-term performance of the banks. Sustainable continuous short-term performance affects the financial stability of banks. Therefore, modified financial intermediation theory considering the risk transformation process will take the following form.

Figure 8. Performance and Risk Transformation Process of Banks Under Financial Intermediation Theory

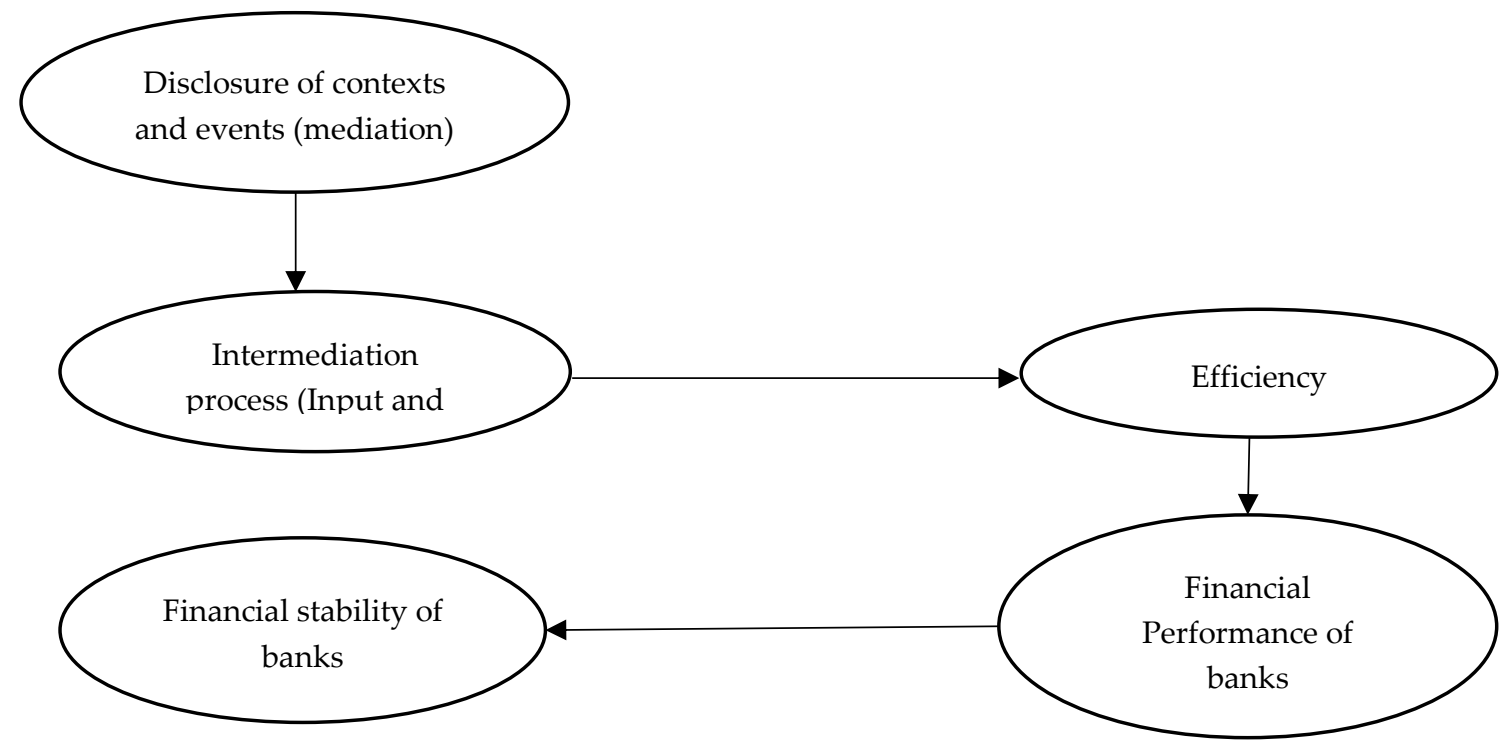




\subsection{Limitations Of Risk Components in Performance Measures}

The most of considered papers had considered accounting ratios to measure the performance of banks i.e. return on assets, return on equity, net interest margin, among other measures. The Z-score also has been considered as a measure of performance. We believe accounting ratios measure the shortterm financial performance of banks and Z-score measures the long-term performance of banks. Therefore, we are of the view that the performance of banks has to be measured considering the risk transformation process of banks using a composite index to capture all the risks. The weights for the variables have to be decided on the respective weights of the components represent in the balance sheet of banks. There were some initiatives of developing such indices. Maqbool \& Zameer (2018 develop a composite performance index but it does not consider the risk components. Rashid \& Jabeen (2016) develop a financial performance index using CAMELS variables. However, they give equal weights for the selected variables which do not reflect the actual risk levels of banks. Our analysis focuses on studies of performance measurement. However, measurement error is not the only major challenge to the empirical studies of bank performance. For example, the study of performance is subject to endogeneity problems, which include not only measurement errors but also other issues such as omitted confounding factors, unobserved heterogeneities, and simultaneity, among others.

\subsection{Dominance of Empirical Research}

The review shows that all the research articles were based on secondary data. There is a dearth of empirical studies in African and some other emerging countries. This may be due to the cost involved in accessing bank-level data from databases as well as limitations of disclosure requirements in underdeveloped capital markets.

\subsection{Limited Studies in Emerging Countries}

There were only 85 single-country studies of which 25 were in emerging countries. The remaining 79 articles were inter country or international studies.

Table 10. Details of Single Country Studies

\begin{tabular}{cccc}
\hline Country & Number of articles & Country & Number of articles \\
\hline Australia & 1 & Kenya & 1 \\
Austria & 2 & South Korea & 1 \\
Bangladesh & 3 & Malaysia & 3 \\
Brazil & 2 & Nigeria & 6 \\
Canada & 1 & Pakistan & 3 \\
China & 10 & Romania & 3 \\
Czech Republic & 2 & Saudi Arabia & 1 \\
Egypt & 1 & Spain & 1 \\
France & 1 & Taiwan & 2 \\
Germany & 1 & Tunisia & 1 \\
Greece & 2 & Turkey & 9 \\
India & 7 & United Arab Emirates & 2 \\
Indonesia & 2 & The USA & 12 \\
Iran & 1 & Yemen & 2 \\
Italy & 1 & & 85 \\
Japan & 1 & Total & \\
\hline
\end{tabular}


Table 11. Details of Inter-Country Studies

\begin{tabular}{cc}
\hline Group & Number of articles \\
\hline Developed Countries & 9 \\
Middle Eastern and North African countries & 11 \\
European Countries & 13 \\
Asian Countries & 18 \\
Developed Vs Developing countries & 2 \\
International without considering specific regions & 19 \\
Developing countries & 2 \\
African Countries & 4 \\
Latin American Countries & \multicolumn{2}{c}{1} \\
\hline Total & $\mathbf{7 9}$ \\
\hline
\end{tabular}

\section{Conclusion}

The main objective of this literature review was to identify and analyze the literature on the performance of banks to understand the research context in-depth to contribute theoretical development in bank risk transformation process. We identified and analyzed 164 research articles published during 2008-2020 on the performance of banks by adopting a systemic literature review methodology. There is a trend of increasing the number of research articles over time. However, there is a limitation of linking performance with the financial intermediation process. The major focus of performance studies was to determine the financial performance and efficiency of banks based on a given event or context. However, researchers were reluctant to adopting risk-based performance measures to capture the risk transformation process in financial intermediation. Therefore, in summary from the complete discussion, it is concluded that future research should focus on extending financial intermediation theory considering the effect of context and events on the intermediation process and performance of banks.

This literature review on performance measures of banks has highlighted conceptual and methodological issues which may serve as guidance for future research

Table 12. Conclusions on Research Questions

\begin{tabular}{cc}
\hline Research question & Main conclusion \\
\hline How articles are placed in time? & $\begin{array}{r}\text { Publication of articles shows an increasing trend over time which may } \\
\text { be due to the continuous development in the banking industry in } \\
\text { different dimensions giving events and context for researchers to study } \\
\text { the performance. Further, the financial crisis and recent economical }\end{array}$ \\
slow down have fuelled the performance studies.
\end{tabular}


We considered only the banking process. However, management related theories are also important in this kind of analysis. It is suggested to consider the following areas for future research:

- One such avenue warranting research attention is the impact of the behavior of the management of banks as we proposed in figure 8. Existing research literature focuses on the impact of management and various determinants on the performance of banks but left the risk transformation process in the banking aspect.

- Future research can also be directed toward the establishment of banking sector-specific measures for measuring performance in different segments i.e. conventional vs. Islamic, commercial vs. investment, savings vs. development, among other classifications, adopts different banking practices in the intermediation process, hence there may be an impact on performance. Further, future studies may focus on interdisciplinary perspectives in performance studies. Besides, to focus on more important external factors such as market risk, competition and market power, and concentration. Therefore, the formulation of the conceptual framework required.

Author Contributions:: Conceptualization, S.D.J, W.P. and R.A.; methodology, W.P.; software, S.D.J.; validation, S.D.J, W.P. and R.A.; formal analysis, S.D.J.; investigation, S.D.J.; resources, S.D.J.; data curation, S.D.J, W.P, and RA.; writing - original draft preparation, SDJ.; writing - review and editing, SDJ.; visualization, SDJ.; supervision, W.P and R.A.; project administration, W.P and R.A.; funding acquisition, n.a. All authors have read and agreed to the published version of the manuscript.

Funding: .This research received no external funding.

Acknowledgments: The authors are grateful to the anonymous referees of the journal for their extremely valuable comments and suggestions to improve the quality of the paper.

Conflicts of Interest: The authors declare no conflict of interest.

\section{References}

ABDC. (2019). 2019 ABDC Journal Quality List. Retrieved from https://abdc.edu.au/research/abdc-journal-list/.

Adesina, K. S. (2019). Bank technical, allocative and cost efficiencies in Africa: The influence of intellectual capital. North American Journal of Economics and Finance, 48, 419-433. doi:10.1016/j.najef.2019.03.009

Alam, N., Zainuddin, S. B., \& Rizvi, S. R. (2019). Ramifications of varying banking regulations on performance of Islamic Banks. Borsa_Istanbul Review, 19(1), 49-64. doi:10.1016/j.bir.2018.05.005

Alcober, M. G., Prior, D., Ausina, E. T., \& Illueca, M. (2019). ARTICLERisk-taking behavior, earnings quality, and bankperformance: A profit frontier approach. Business Research Quarterly, Article in Press. doi:10.1016/j.brq.2019.02.003

Andres, P. d., \& Vallelado, E. (2008). Corporate governance in banking: The role of the board of directors. Journal of Banking E Finance, 32, 2570-2580. doi:10.1016/j.jbankfin.2008.05.008

Ashraf, D., Rizwan, M. S., \& Huillier, B. L. (2016). A net stable funding ratio for Islamic banks and its impact on financialstability: An international investigation. Journal of Financial Stability, 25, 47-57. doi:10.1016/j.jfs.2016.06.010

Athanasoglou, P. P., Brissimis, S. N., \& Delis, M. D. (2008). Bank-specific, industry-specific and macroeconomic determinants of bank profitability. International Financial Markets, Institutions. and Money, 18, 121-136. doi:10.1016/j.intfin.2006.07.001

Azad, A. S., Azmat, S., \& Hayat, A. (2019). What determines the profitability of Islamic banks: Lending or fee? International Review of Economics and Finance, Article in press. doi:10.1016/j.iref.2019.05.015

Bandt, O. D., Camara, B., Maitre, A., \& Pessarossi, P. (2018). Optimal capital, regulatory requirements and bank performance intimes of crisis: Evidence from France. Journal of Financial Stability, 175-186. doi:10.1016/j.jfs.2017.03.002

Barros, C. P., \& Williams, J. (2013). The random parameters stochastic frontier cost function and the effectiveness of public policy: Evidence from bank restructuring inMexico. International Review of Financial Analysis, 30, 96-108. doi:10.1016/j.irfa.2013.06.006

Barros, C. P., Chen, Z., Liang, Q. B., \& Peypoch, N. (2011). Technical efficiency in the Chinese banking sector. Economic Modelling, 28, 2083-2089. doi:doi:10.1016/j.econmod.2011.04.003 
Batir, T. E., Volkman, D. A., \& Gungor, B. (2017). Determinants of bank efficiency in Turkey: Participation banks versus conventional banks. Borsa_Istanbul Review, 17(2), 86-96. doi:10.1016/j.bir.2017.02.003

Beck, T., Demirgüç-Kunt, A., \& Merrouche, O. (2013). Islamic vs. conventional banking: Business model, efficiency and stability. Journal of Banking $\mathcal{E}$ Finance, 37, 433-447. doi:10.1016/j.jbankfin.2012.09.016

Berger, A. N., \& Mester, L. J. (1997). Inside the Black Box: What Explains Differences in the Efficiencies of Financial Institutions. Journal of Banking and Finance, 21, 895-947.

Berger, A. N., Klapper, L. F., \& Turk-Ariss , R. (2009). Bank Competition and Financial Stability. Journal of Financial Services Research, 35(2), 99-118. doi:10.1007/s10693-008-0050-7

Berger, A. N., \& Bouwman, C. H. (2013). How doescapitalaffectbankperformanceduringfinancial crises? JournalofFinancialEconomics, 109, 146-176. doi:10.1016/j.jfineco.2013.02.008

Berger, A. N., \& Young, R. D. (1997). Problem loans and cost efficiency in commercial banks. Journal of Banking $\mathcal{E}$ Finance, 21, 849-870.

Berger, A. N., Boubakri, N., Guedhami, O., \& Li, X. (2019). Liquidity creation performance and financial stability consequences ofIslamic banking: Evidence from a multinational study. Journal of Financial Stability, 44, 117. doi:10.1016/j.jfs.2019.100692

Berger, A. N., Hasan, I., \& Zhou, M. (2010). The effects of focus versus diversification on bank performance: Evidence from Chinese banks. Journal of Banking $\mathcal{E}$ Finance, 34, 1417-1435. doi:10.1016/j.jbankfin.2010.01.010

Berger, A. N., Kick, T., \& Schaeck, K. (2014). Executive board composition and bank risk taking. Journal of Corporate Finance, 28, 48-65. doi:10.1016/j.jcorpfin.2013.11.006

Bertay, A. C., Demirgüç-Kunt, A., \& Huizinga, H. (2013). Do we need big banks? Evidence on performance,strategy and market discipline. Journal of Finanancial Intermediation(22), 532-558. doi:10.1016/j.jfi.2013.02.002

Bian, W., \& Deng, C. (2017). Ownership dispersion and bank performance: Evidence from China. Finance Research Letters, 22, 49-52. doi:10.1016/j.frl.2016.12.030

Boubakri, N., Mirzaei, A., \& Samet, A. (2017). National culture and bank performance: Evidence from the recentfinancial crisis. Journal of Financial Stability, 29, 36-56. doi:10.1016/j.jfs.2017.02.003

Brissimis, S. N., Delis, M. D., \& Papanikolaou, N. I. (2008). Exploring the nexus between banking sector reform and performance: Evidence from newly acceded EU countries. Journal of Banking \& Finance, 32, 2674-2683. doi:10.1016/j.jbankfin.2008.07.002

CABS. (2020). Chartered Association of Business Schools. Retrieved from Academic Journal Guide 2018 : https://charteredabs.org/academic-journal-guide-2018-view/

Chen, H. K., Liao, Y. C., Lin, C. Y., \& Yen, J. F. (2018). The effect of the political connections of government bank CEOs onbank performance during the financial crisis. Journal of Financial Stability, 36, 130-143. doi:10.1016/j.jfs.2018.02.010

Chen, N., Liang, H. Y., \& Yu, M. T. (2018). Asset diversification and bank performance: Evidence from three Asian countries with a dual banking system. Pacific-Basin Finance Journal, 52, 40-53. doi:10.1016/j.pacfin.2018.02.007

Chortareas, G. E., Girardone, C., \& Ventouri, A. (2012). Bank supervision, regulation, and efficiency: Evidence from the European Union. Journal of Financial Stability, 8, 292-302. doi:10.1016/j.jfs.2011.12.001

Claessens, S., Coleman, N., \& Donnelly, M. (2018). “Low-For-Long”interest rates and banks' interest margins and profitability: Cross-country evidence. J. Finan. Intermediation(35), 1-16. doi:10.1016/j.jfi.2017.05.004

Colesnic, O., Kounetas, K., \& Michael, P. (2019). Estimating risk efficiency in Middle East banks before and after the crisis: A metafrontier framework. Global Finance Journal, Article in press. doi:10.1016/j.gfj.2019.100484

Cornett, M. M., Guo, L., Khaksari, S., \& Tehranian, H. (2010). The impact of state ownership on performance differences in privately-owned versus state-owned banks: An international comparison. Journal of Financial Intermediation, 19, 74-94. doi:10.1016/j.jfi.2008.09.005

Cubillas, E., Fonseca, A. R., \& González, F. (2012). Banking crises and market discipline: International evidence. Journal of Banking \& Finance, 36, 2285-2298. doi:10.1016/j.jbankfin.2012.04.011

Das, A., \& Ghosh, S. (2006). Financial deregulation and efficiency: An empirical analysis of Indian banks during the post reform period. Review of Financial Economics, 15, 193-221.

Dedu, V., \& Chitan, G. (2013). The influence of internal corporate governance on bank performance - an empirical analysis for Romania. Procedia - Social and Behavioral Sciences, 99, 1114-1123. 
Demirguc--Kunt, A., \& Huizinga, H. (2010). Bank activity and funding strategies:The impact on risk and returns. Journal of Financial Economics, 98, 626-650. doi:10.1016/j.jfineco.2010.06.004

Ding, D., \& Sickles, R. C. (2018). Frontier efficiency, capital structure,and portfolio risk: An empirical analysis of U.S. banks. Business Researc hQuarterly, 21, 262-277. doi:10.1016/j.brq.2018.09.002

Distinguin, I., Roulet, C., \& Tarazi, A. (2013). Bank regulatory capital and liquidity: Evidence from US and European publicly traded banks. Journal of Banking $\mathcal{E}$ Finance, 37, 3295-3317. doi:10.1016/j.jbankfin.2013.04.027

Djalilov, K., \& Piesse, J. (2019). Bank regulation and efficiency: Evidence from transition countries. International Review of Economics and Finance, 64, 308-322. doi:10.1016/j.iref.2019.07.003

Fang, J., Lau, C.-K. M., Lu, Z., Tan, Y., \& Zhang, H. (2019). Bank performance in China: A Perspective from Bank efficiency, risk-taking and market competition. Pacific-Basin Finance Journal, 56, 290-309. doi:10.1016/j.pacfin.2019.06.011

Fink, A. (2005). Conducting Research Literature Reviews: From the Internet to Paper. New Delhi: Sage Publications.

Fu, X., Lin, Y., \& Molyneux, P. (2014). Bank competition and financial stability in Asia Pacific. Journal of Banking $\mathcal{E}$ Finance, 38, 64-77. doi:10.1016/j.jbankfin.2013.09.012

Fukuyama, H., \& Matousek, R. (2011). Efficiency of Turkish banking: Two-stage network system. Variable returns to scale model. Journal of International Financial Markets, Institutions $\mathcal{E}$ Money, 21, 75-91. doi:10.1016/j.intfin.2010.08.004

García-Herrero, A., Gavilá, S., \& Santabárbara, D. (2009). What explains the low profitability of Chinese banks? Journal of Banking E Finance, 33, 2080-2092.

Gerhardt, M., \& Vennet, R. V. (2017). Bank bailouts in Europe and bank performance. Finance Research Letters, 22, 74-80. doi:0.1016/j.frl.2016.12.028

Ghosh, S. (2018). Governance reforms and performance of MENA banks: Are disclosures effective? Global Finance Journal, 78-95. doi:10.1016/j.gfj.2018.01.002

Gunes, H., \& Yildirim, D. (2016). Estimating cost efficiency of Turkish commercial banks under unobserved heterogeneity with stochastic frontier models. Central Bank Review, 16, 127-136. doi:10.1016/j.cbrev.2016.12.001

Henriques, I. C., Sobreiro, V. A., \& Kimura, H. (2018). Efficiency in the Brazilian banking system using data envelopment analysis. Future Business Journal, 4, 157-178. doi:https://doi.org/10.1016/j.fbj.2018.05.001

Hong, H., Huang, J.-Z., \& Wu, D. (2014). The information content of Basel III liquidity risk measures. Journal of Financial Stability, 15, 91-111. doi:10.1016/j.jfs.2014.09.003

Huang, T. H., Chiang, D. L., \& Chao, S. W. (2017). A new approach to jointly estimating the Lerner index and costefficiency for multi-output banks under a stochastic meta-frontierframework. The Quarterly Review of Economics and Finance, 65, 212-226. doi:http://dx.doi.org/10.1016/j.qref.2016.09.004

Huang, T.-H., Chiang, D.-L., \& Lin, C.-I. (2017). A new approach to estimating a profit frontier using the censored stochastic frontier model. North American Journal of Economics and Finance, 39, 68-77. doi:10.1016/j.najef.2016.12.001

Hughes, J. P., Jagtiani, J., Mester, L. J., \& Moon, C. G. (2019). Does scale matter in community bank performance? Evidence obtained by applying several new measures of performance. Journal of Banking and Finance, 106, 471-499. doi:10.1016/j.jbankfin.2019.07.005

Hughes, J., \& Mester, L. (2015). Measuring the performance of banks: theory, practice, evidence and policy implications. In The Oxford Handbook of Banking (Second ed., pp. 247-270). Oxford University Press.

Hung, C.-H. D., Jiang, Y., Liu, F. H., Tu, H., \& Wang, S. (2017). Bank political connections and performance in China. Journal of Financial Stability, 32, 57-69. doi:10.1016/j.jfs.2017.09.00

James, B. J., \& Joseph, C. (2015). Corporate Governance Mechanisms and Bank Performance : Resource- Based View. Procedia Economics and Finance, 31, 117-123.

Khan, H. H., Ahmad, R. B., \& Chan, S. G. (2018). Market structure, bank conduct and bank performance:Evidence from ASEAN. Journal of Policy Modeling, 40, 934-958. doi:10.1016/j.jpolmod.2018.02.001

King, T., Srivastav, A., \& Williams, J. (2016). What's in an education? Implications of CEO education for bank performance. Journal of Corporate Finance, 37, 287-308. doi:10.1016/j.jcorpfin.2016.01.003

Köhler, M. (2015). Which banks are more risky? The impact of business models onbank stability. Journal of Financial Stability, 16, 195-212. doi:10.1016/j.jfs.2014.02.005 
Kosmidou, K. (2008). The determinants of banks' profits in Greece during the period of EU financial integration. Managerial Finance, 34(3), 146-159.

Köster, H., \& Pelster, M. (2017). Financial penalties and bank performance. Journal of Banking and Finance, 79, 5773. doi:http://dx.doi.org/10.1016/j.jbankfin.2017.02.009

Kutubi, S. S., Ahmed, K., \& Khan, H. (2018). Bank performance and risk-taking- Does directors' busyness matter? Pacific-Basin Finance Journal, 50, 184-199. doi:10.1016/j.pacfin.2017.02.002

Mahbub, T., Matthew, K., \& Barker, K. (2019). Other people's money:The profit performance of Bangladeshi family dominated banks. Journal of Behavioraland Experimental Finance, 21, 103-112. doi:10.1016/j.jbef.2018.11.005

Majid, M. A., Falahaty, M., \& Jusoh, M. (2017). Performance of Islamic and conventional banks: A meta-frontier approach. Research in International Business and Finance, 42, 1327-1335.

Mansour, R., \& Moussawi, C. E. (2019). Efficiency, technical progress and productivity of Arab banks:A nonparametric approach. The Quarterly Review of Economics and Finance, Article in press. doi:10.1016/j.qref.2019.02.002

Manthos , D., \& Nikolaos , I. I. (2009). Determinants of bank efficiency: Evidence from a semiparametric mathodology. Managerial Finance, 35(3), 260-275.

Maqbool, S., \& Zameer, M. N. (2018). Corporate socialresponsibilityand financial performance:An empirical analysisofIndianbanks. Future BusinessJournal, 4, 84-93. doi:10.1016/j.fbj.2017.12.002

Meca, E. G., Sánchez, I., \& Ferrero, J. M. (2015). Board diversity and its effects on bank performance: An international analysis. Journal of Banking \& Finance, 53, 202-214. doi:10.1016/j.jbankfin.2014.12.002

Miller, S. M., \& Noulas, A. G. (1996). The technical efficiency of large bank production. Journal of Banking and Finance, 20, 495-509.

Mirzaei, A., Moore, T., \& Liu, G. (2013). Does market structure matter on banks' profitability and stability? Emerging vs. advanced economies. Journal of Banking $\mathcal{E}$ Finance, 37, 2920-2937. doi:10.1016/j.jbankfin.2013.04.031

Musali, M. K., \& Ismail, K. I. (2014). Intellectual capital and its effect on financial performance of banks: Evidence from Saudi Arabia. Procedia - Social and Behavioral Sciences, 164, 201-207.

Naceur, S. B., \& Kandil, M. (2009). The impact of capital requirements on banks' cost of intermediation and performance: The case of Egypt. Journal of Economics and Business, 61, 70-89. doi:10.1016/j.jeconbus.2007.12.001

Naceur, S. B., \& Omran, M. (2010). The Effects of Bank Regulations, Competition, and Financial Reforms on Banks' Performance. Emerging Markets Review, 12(1), 1-20. doi: · 10.1016/j.ememar.2010.08.002

Onakoya, O. A., Moses, C. L., Olokundun, M. A., Okorie, U. E., \& Lawal, F. A. (2018). Data set on managerial incentives and bank performance: Evidence from Nigerian deposit money banks. Data in Brief, 19, 878-882. doi:10.1016/j.dib.2018.05.093

Oyewumi, O. R., Ogunmeru, O. A., \& Oboh, C. S. (2018). Investment in corporate social responsibility, disclosure practices, and financial performance of banks in Nigeria. Future Business Journal, 4, 195-205. doi:https://doi.org/10.1016/j.fbj.2018.06.004

Partovi, E., \& Matousek, R. (2019). Bank efficiency and non-performing loans: Evidence from Turkey. Research in International Business and Finance, 48, 287-309. doi:https://doi.org/10.1016/j.ribaf.2018.12.011

Pathan, S., \& Faff, R. (2013). Does board structure in banks really affect their performance? Journal of Banking $\mathcal{E}$ Finance, 37, 1573-1589. doi:10.1016/j.jbankfin.2012.12.016

Psillaki , M., \& Mamatzakis, E. (2017). What drives bank performance in transitions economies? The impact of reforms and regulations. Research in International Business and Finance, 39, 578-594. doi:10.1016/j.ribaf.2016.09.010

Rashid, A., \& Jabeen, S. (2016). Analyzing performance determinants: Conventional versus Islamic Banks in Pakistan. Borsa Istanbul Review.

Robin, I., Salim, R., \& Bloch, H. (2018). Financial performance of commercial banks in the post-reform era: Further evidence from Bangladesh. Economic Analysis and Policy, 58, 43-54.

Rossi, S. P., Schwaiger, M. S., \& Winkler, G. (2009). How loan portfolio diversification affects risk, efficiency and capitalization: A managerial behavior model for Austrian banks. Journal of Banking E Finance, 33, 22182226. doi:10.1016/j.jbankfin.2009.05.022

Sathye , M. (2001). X-effciency in Australian banking: An empirical investigation. Journalof Banking \& Finance, 25, 613-630. 
Seçme , N. Y., Bayrakdaroğlu, A., \& Kahraman , C. (2009). Fuzzy performance evaluation in Turkish Banking Sector using Analytic Hierarchy Process and TOPSIS. Expert Systems with Applications, 36(9), 11699-11709. doi:10.1016/j.eswa.2009.03.013

Shamshur, A., \& Weill, L. (2019). Does bank efficiency influence the cost of credit? Journal of Banking and Finance, 105, 62-73. doi:10.1016/j.jbankfin.2019.05.002

Shim, J. (2013). Bank capital buffer and portfolio risk: The influence of business cycle and revenue diversification. Journal of Banking \& Finance, 37, 761-772. doi:10.1016/j.jbankfin.2012.10.002

Shukla, M., \& Jharkharia (, S. (2013). Agri-fresh produce supply chain management: a state-of-the-art literature review. International Journal of Operations $\mathcal{E}$ Production Management, 33(2), 114-158. doi:10.1108/01443571311295608

Silva, T. C., Tabak, B. M., Cajueiro, D. O., \& Dias, M. V. (2017). A comparision of DEA and SFA using micro-and macro-level perspectives: efficiency of Chinese local banks. Physica A: Statistical Mechanics and its Applications, 469, 216-223.

Silva, T. C., Tabak, B. M., Cajueiro, D. O., \& Dias, M. V. (2018). Adequacy of deterministic and parametric frontiers to analyze the efficiency of Indian commercial banks. Physica A, 506, 1016-1025. doi:10.1016/j.physa.2018.04.100

Singh, H. P., \& Kumar, S. (2014). Working capital management: a literature review and research agenda. Qualitative Research in Financial Markets, 6(2), 173-197. doi:10.1108/QRFM-04-2013-0010

Sufian, F., Kamarudin, F., \& Nassir, A. M. (2016). Determinants of efficiency in the malaysian banking sector: Does bank origins matter? Intellectual Economics, 10, 38-54.

Tecles, P. L., \& Tabak, B. M. (2010). Determinants of bank efficiency: The case of Brazil. European Journal of Operational Research(3), 1587-1598.

Toloo, M., \& Mensah, E. K. (2019). Robust optimization with nonnegative decision variables: A DEA approach. Computers E Industrial Engineering, 313-325. doi:10.1016/j.cie.2018.10.006

Tsai, Y.-S., Lin, C.-C., \& Chen, H.-Y. (2015). Optimal diversification, bank value maximization and default probability. Applied Economics, 47(24), 2488-2499. doi:10.1080/00036846.2015.1008766

Uhde, A., \& Heimeshoff, U. (2009). Consolidation in banking and financial stability in Europe: Empirical evidence. Journal of Banking \& Finance, 33, 1299-1311. doi:10.1016/j.jbankfin.2009.01.006

Zuhroh, I., Ismail, M., \& Maskie, G. (2015). Cost Efficiency of Islamica Banks in Indonesia - AStochastic Frontier Analysis. Procedia-Sicial and Behavioral Sciences, 211, 1122-1131.

(C) 2020 by the authors. This article is an open-access article distributed under the terms and conditions of the Creative Commons Attribution (CC BY) license (http://creativecommons.org/licenses/by/4.0/). 